\title{
A Study on the Knowledge, Attitude, and Practice of Critical Thinking Skills among EFL Teachers in Iran
}

\author{
Mahdieh Ghaani ${ }^{1}$ and Vizayaletchumi Pauline Roslin ${ }^{2 *}$
}

1,2 Faculty of Persian Literature and Foreign Languages, Islamic Azad

University, Roudehen, Iran

\section{*Corresponding Author: \\ $\leadsto$ vprosline@yahoo.com}

Received: 15 February, 2021

Accepted: 19 March, 2021

Published: 28 April, 2021

\begin{abstract}
The main aim of this descriptive survey study was to explore Iranian EFL teachers' knowledge, attitude, and practice of Critical Thinking (CT) skills. This study differs from previous studies in that the knowledge construct assessed was framed to find out if participants knew what the concept of core-skills of CT skills meant. Also, contrary to previous studies, the type(s) of CT skills (core and subskills) practiced within individual language skills training classes was studied in this study. To this effect, 276 male and female EFL teachers completed the Knowledge of CT skills, the California Critical Thinking Disposition Inventory and the Classroom Practice of CT skills pre-tested self-report questionnaires. Subsequent to running non-parametric one sample Wilcoxon Rank Order tests on the data collected, the most important finding in the present study was that the EFL teachers demonstrated poor overall knowledge of the concept of core CT skills though their attitude towards CT was significantly positive. The results also showed that overall, not much CT skills practice was implemented in language skill-based classes, especially in the listening classes where a significant number did not practice any of the CT sub-skills assessed. On the contrary, a significant number of teachers reported practicing almost all the CT sub-skills in their speaking classes. Thus, this study suggests that another important contributing factor of the lack of practice of CT skills in the EFL context to probably be teachers' lack of understanding of the concept and skills related to the theory of CT. This is significant as it is believed that when teachers understand how theory informs practice, they usually come to be more open to the possibility that theory really matters in the context of education.
\end{abstract}

Keywords: Knowledge, Attitude, Practice of Critical Thinking Skills

\section{Introduction}

In the field of language learning, researchers have identified critical thinking as one of the predictors of overall academic performance $[1,2,3]$ and also confirmed its role in improving ESL writing ability [4], vocabulary learning strategy instruction, language proficiency [5]; and oral communication ability [6]. Others have emphasized the importance of developing higher-order thinking skills in foreign language classrooms [7, 8]. Also, empirical evidence has supported the effectiveness of teaching critical thinking skills along with foreign languages [9,
10, 11]. In fact, language learners who have developed critical thinking skills were found to be capable of doing activities of which other students may not be capable [12]. These researchers implied that language learners with critical thinking ability are capable of thinking critically and creatively in order to achieve the goals of the curriculum; capable of making decisions and solving problems; capable of using their thinking skills, and of understanding language or its contents; capable of treating thinking skills as lifelong learning; 
and finally intellectually, physically, emotionally and spiritually well-balanced.

As far as classroom teaching is concerned, Mayfield [13] goes on to explicate that a possible way to raise students' awareness of critical thinking is to involve them explicitly in critical thinking opportunities. However, it is believed that for various reasons, teachers still draw on traditional teaching approaches in many language classrooms. One of the reasons for implementing the traditional teaching approaches in language classrooms is given to be the teachers own learning experience. It is believed that teachers find it difficult to engage learners in critical thinking activities as it was not how they had learned or how they were taught to teach [14]. Also, the traditional method teachers are said to have an overwhelming conscientious to impart knowledge and provide correct answers [15]. Other researchers point out that language learning and thinking skills are often treated as independent processes in typical language learning settings [16, 17]. In other words, in the tradition of English language teaching methodology, the integration of language and thinking skills has been peripheral [18]. The literature on foreign language teaching echoes the need to incorporate critical thinking into English language pedagogy $[19,20]$. In this context, language teachers are said to play a crucial role in developing critical thinking skills among learners [21]. Even though research on critical thinking highlights the importance of teachers who can enhance students' critical thinking skills [22, 23], little attention has been given to how EFL teachers conceptualize and integrate critical thinking. Among the few studies done, only one reported that language teachers in Iran view critical thinking as a pedagogical goal in English language classes but had vague and limited conceptions of critical thinking [24].

Thus, as Facione reiterates, for the infusion of critical thinking into the education system, teachers should be educated to model critical thinking [25]. It is also believed that a trained teacher in Critical Thinking skills is able to encourage and model thinking behaviors in the process of instruction to improve leaner's ability [26]. Yet, many teachers resist the need to understand theory because they perceive that their job is about practice. It was once stated that when teachers understand how theory informs practice and that the two are intrinsically linked, they usually come to be more open to the possibility that theory really matters [27].

\section{Method}

\section{Participants}

The sample chosen as the subset of the population involved in this study consisted of EFL teachers currently teaching regular EFL classes in language institutes spread over various regions in Tehran province as well as other cities. This is important for this study as one of the aims of this study was to find out if EFL teachers showed any statistically significant differences in their knowledge, attitude and practice of Critical Thinking Skills and choosing participants from various venues would provide a more reliable result. Besides, the potential participants approached were those in the intermediate, upper Intermediate and advance English Language proficiency levels. This was to avoid problems in comprehension of and response to the questionnaires due to low language proficiency which might affect data reliability. Chosen by means of convenience sampling, participants of the main study consisted of 276 female and male EFL teachers from language institutes in Tehran, Qazvin and Arak.

\section{Instruments}

This study used three self-report scales as instruments to collect data. It should be mentioned that the statements/questions in all three questions are related to the definitions of the core critical thinking skills introduced by Facione [28]. The instruments utilized to collect the pertinent data in the present study were: (a) Knowledge of Critical Thinking Skills Questionnaire (b) CCTDI-California Critical Thinking Disposition (c) Practice of Critical Thinking Skills Questionnaire.

The questionnaire related to participants' demographic variables was marked as I, the knowledge was marked II, Attitude was III and Practice was marked III. Questionnaire administration adhered to this sequence as it revolves around the aim of this study. These are outlined next.

\section{Knowledge of critical thinking skills questionnaire}

The teachers' knowledge of the core critical thinking skills were assessed using a researcher-made questionnaire consisting sample questions related to each skill adapted from Critical Thinking Skill Test (CTST) User Manual and Resource Guide (C) 2016.

The participants were asked to choose the skill that fits the statement they read from among the six core critical thinking skills. If the answer was correct they gave a score of 1 for that particular item while a score 0 was allocated to any item which had a negative response. As the test aimed to measure six core critical thinking skills, the average value of the items corresponding to each subscale was calculated and presented.

As the scale of the knowledge was measured in a binary fashion ( 0 or 1$)$, the range of the scores were between 0 and 1 . Therefore, the expected median was 0.5. So, participants who scored above the median were categorized as having good knowledge, whereas those 
who scored below the median were categorized as having poor knowledge.

\section{Attitude towards critical thinking skills}

The attitude of the respondents was measured using The California Critical Thinking Disposition Inventory (CCTDI) by Facione and Facione [29]. The CCTDI has 75 questions measured by 6 points Likert scale $(1=$ strongly disagree, $2=$ disagree, $3=$ fairly disagree, $4=$ fairly agree, $5=$ agree and $6=$ strongly agree).

This inventory is an online testing tool. Since, the request to publishers to use this tool for this study was rejected, the researcher had to resort to measure respondents' attitude towards CT using the average score of the participants on the 6-point Likert scale. So, the possible range of the scores was 1 to 6 and the expected median was obtained from the following formula: (lower band + upper band) $/ 2 \rightarrow(1+6) / 2=$ 3.5 .

In accordance with the scoring mode of this tool, participants whose scores were lower than 3.5 median were categorized as being negatively disposed toward critical thinking, whereas those who scored above the median were categorized as being positively disposed toward critical thinking.

\section{Practice of critical thinking skills}

The level of the teachers' practice of the six types of core Critical Thinking Skills in their respective language skill-based classes were assessed through a researchermade questionnaire.

The questionnaire composed of a table with the six types of core Critical Thinking Skills as identified by related studies followed by explanations of these skills and their respective subskills (16 overall). This follows the advice by Riddell [30] who noted that critical thinking should not be defined but explained by its components and features, stages, and characteristics as how critical thinking experts have done.

Respondents had to tick the sub-skills that he/she normally practices with the EFL students in his/her respective skill- based classes. The teachers had to put a check mark on the skill(s) they practiced in each skillbased class (Score $=1$ ) and leave those they did not, blank (Score $=0)$.

This instrument explores the participants' knowledge of six components of CT using thirty-nine questions. These questions were related to the six core critical thinking skills which are Interpretation (1), Analysis (2), Evaluation (3), Inference (4), Explanation (5) and SelfRegulation (6) [28].

\section{Results}

The three questions posed in this study called for descriptive analyses of the data collected. These research questions were answered by providing the mean score of the participants to each instrument and running one-sample tests. The following sub-sections provides the details of the descriptive and inferential statistics used to answer them.

RQ1. To what extent do Iranian EFL teachers have the Knowledge of Critical Thinking skills?

To answer the first research question, the participants' answers to the knowledge of CT Skills questionnaire were averaged under each critical thinking sub-scales. Table 1 shows the descriptive statistics of the results.

Table 1

Descriptive statistics of the average scores of the knowledge of CT skills

\begin{tabular}{lccccccc}
\hline & $\mathbf{N}$ & Minimum & Maximum & Mean & Std. Deviation & \multicolumn{2}{c}{ Skewness } \\
\cline { 2 - 8 } & Statistic & Statistic & Statistic & Statistic & Statistic & Statistic & Std. Error \\
\hline Interpretation & 276 & .00 & 1.00 & .2778 & .19262 & .464 & .147 \\
Analysis & 276 & .00 & 1.00 & .2397 & .18585 & .734 & .147 \\
Inference & 276 & .00 & 1.00 & .2629 & .14832 & .720 & .147 \\
Evaluation & 276 & .00 & 1.00 & .2645 & .21313 & .507 & .147 \\
Explanation & 276 & .00 & 1.00 & .2681 & .24181 & .788 & .147 \\
Self-Regulation & 276 & .00 & 1.00 & .2150 & .17776 & .632 & .147 \\
Total & 276 & .03 & .95 & .2416 & .10660 & 1.451 & .147 \\
Valid N (listwise) & 276 & & & & & & \\
\hline
\end{tabular}

Looking into Table 1, it is evident that the highest mean belongs to the interpretation skill $(\mathrm{M}=.278)$ while the self-regulation skill has the lowest mean ( $\mathrm{M}=$ .215). Moreover, as all of the mean scores were lower than .5 , it is an indicative of relatively low rate of knowledge of the CT skills by EFL teachers.

Note that, as the test aimed to measure six subscales (reported above in the table), to present a more organized description of the results, the average value of the items corresponding to each subscales were calculated and presented. For example, the descriptive statistics represented for the subscale of interpretation is based on the average values participants obtained from items 6, 13, 20, 21, 28, and 39 .

In order to see if the mean scores are significant, at first one sample tests were run. However, the skewness

Page | 16 
ratios (Statistics/Std. Error) for all distributions of subskills did not fall within the legitimate range of normal distributions, i.e., \pm 1.96 , they were analyzed using nonparametric one sample Wilcoxon Rank Order test.

Table 2

One-Sample Wilcoxon Signed Rank Tests on Average Scores of the Knowledge of CT Skills

\begin{tabular}{lccccc}
\hline & $\begin{array}{c}\text { Total } \\
\text { N }\end{array}$ & $\begin{array}{c}\text { Test } \\
\text { Statistic }\end{array}$ & $\begin{array}{c}\text { Standard } \\
\text { Error }\end{array}$ & $\begin{array}{c}\text { Standardized } \\
\text { Test Statistic }\end{array}$ & $\begin{array}{c}\text { Asymptotic Sig.(2- } \\
\text { sided test) }\end{array}$ \\
\hline Interpretation & 276 & 1140.000 & 992.884 & -12.230 & .000 \\
Analysis & 276 & 823.000 & 1079.666 & -12.967 & .000 \\
Inference & 276 & 781.000 & 1317.729 & -13.912 & .000 \\
Evaluation & 276 & 2873.500 & 1307.356 & -12.422 & .000 \\
Explanation & 276 & 4075.000 & 1308.086 & -11.496 & .000 \\
Self-Regulation & 276 & 363.000 & 1087.888 & -13.404 & .000 \\
Total & 276 & 295.000 & 1326.067 & -14.191 & .000 \\
\hline
\end{tabular}

The results in Table 2 indicate that in all of the CT subskills, the observed median score was significantly lower than the expected median. Moreover, the total score of the participants in the practice of CT skills questionnaire was significantly lower than the expected median $(\mathrm{Z}=-14.19, \mathrm{p}=.000<.05)$. Therefore, it was concluded that Iranian EFL teachers' knowledge of critical thinking skills is significantly low. Figure 1 pictures the difference between the observed and expected medians. Note that in analyzing the data, the average values for total amounts were used. As the scale of the knowledge was measured in a binary fashion (0 or 1$)$, the range of the scores were between 0 and 1 . Therefore, the expected median was 0.5 .

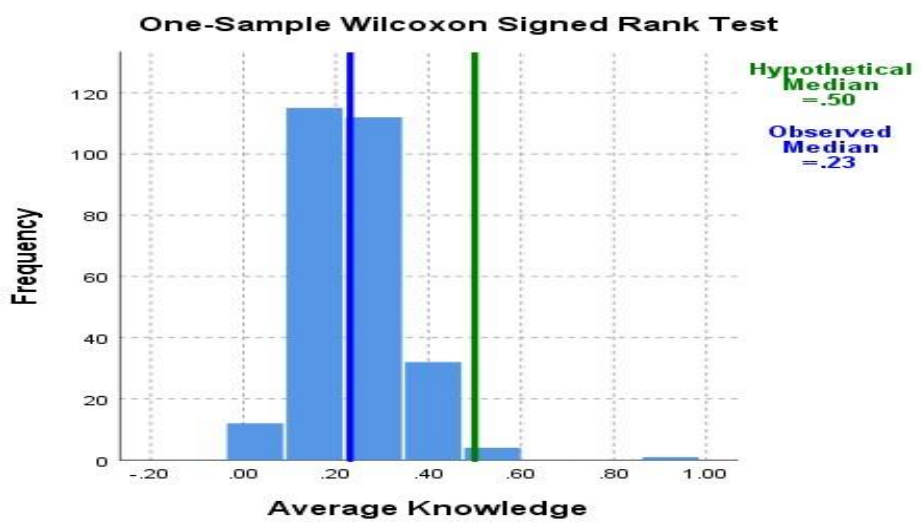

Figure 1. Observed against expected median: Knowledge scores

RQ2. What is the Iranian EFL teachers' attitude towards critical thinking skills?

Table 3

Descriptive statistics of the average scores on CCTDI

\begin{tabular}{|c|c|c|c|c|c|c|c|}
\hline & $\begin{array}{c}\mathrm{N} \\
\text { Statictic }\end{array}$ & Minimum & Maximum & Mean & Std. Deviation & Statictic & Skewness \\
\hline Total & 276 & 1.81 & 5.05 & 3.9448 & .45279 & -.527 & .147 \\
\hline Valid N (listwise) & 276 & & & & & & \\
\hline
\end{tabular}

Looking into Table 3, it is evident that the observed mean score is above the expected mean $(\mathrm{M}=3.94>$ 3.5) indicating that the participants' attitude towards critical thinking is positive.

Note that the descriptive statistics reported are based on the average value, i.e., the total score of the participants were divided by the number of items, obtained by the participants' answers.
To answer the second descriptive research question, the participants' answers to the California Critical Thinking Disposition Inventory were averaged. Table 3 shows the descriptive statistics of the results.
In order to see if the observed mean score is significant, one sample Wilcoxon Signed Rank Test was run. However, as the skewness ratios (-.572 / .147 = $3.59)$ did not fall within the legitimate range of normal distributions, i.e., \pm 1.96 , a non-parametric one sample test was used. 
Table 4

One-Sample signed rank test on average total score of the CCTDI

\begin{tabular}{lccccc}
\hline & Total N & $\begin{array}{c}\text { Test } \\
\text { Statistic }\end{array}$ & $\begin{array}{c}\text { Standard } \\
\text { Error }\end{array}$ & $\begin{array}{c}\text { Standardized } \\
\text { Test Statistic }\end{array}$ & $\begin{array}{c}\text { Asymptotic } \\
\text { Sig.(2-sided test) }\end{array}$ \\
\hline CCTDI Average & 276 & 34454.500 & 1305.642 & 12.066 & .000 \\
\hline
\end{tabular}

The results in Table 4 indicate that the participant have significantly positive $(\mathrm{Z}=12.066, \mathrm{p}=.000<.05)$ attitude towards critical thinking. Therefore, it was concluded that Iranian EFL teachers' attitude towards critical thinking is significantly positive.

Note that, as the average score of the participants were used in the analysis, since the questionnaire was in a 6- point Likert scale form, the possible range of the scores was 1 to 6 and the expected median was obtained from the following formula: (lower band + upper band) $/ 2 \rightarrow$ $(1+6) / 2=3.5$. Figure 2 pictures the difference between observed and expected median.

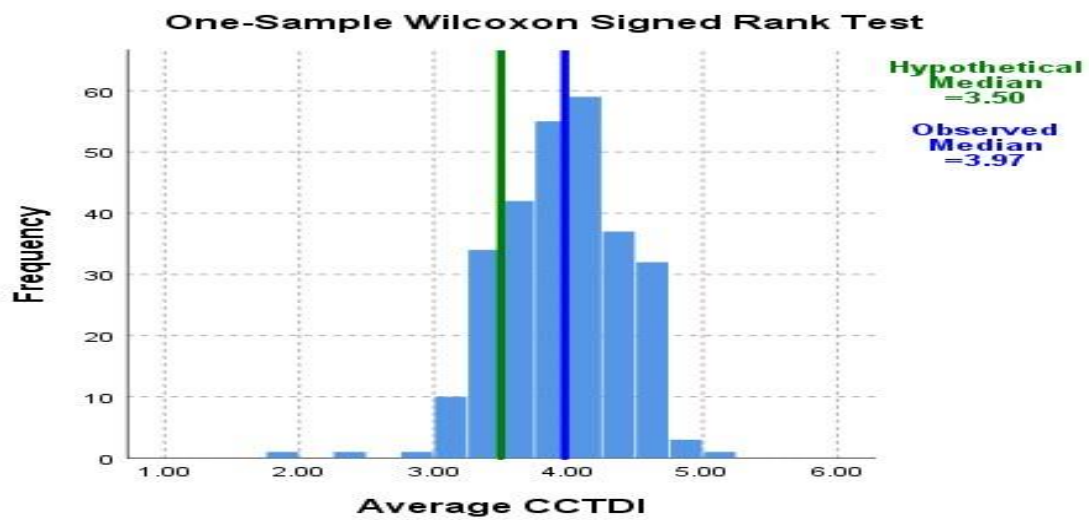

Figure 2. Observed against expected median: CCTDI scores

RQ3. To what extent do Iranian EFL teachers practice Critical Thinking skills in the teaching of various language skills?
The practice questionnaire measured the use of CT core skills and its sub-skills by the participants. Table 5 shows the frequency of the use of these core skills during teaching the four language skills.

Table 5

Frequency of the use of CT core skills within four language skills

\begin{tabular}{|c|c|c|c|c|c|c|c|c|c|}
\hline \multirow{2}{*}{ Core Skills } & & \multicolumn{2}{|c|}{ Listening } & \multicolumn{2}{|c|}{ Speaking } & \multicolumn{2}{|c|}{ Writing } & \multicolumn{2}{|c|}{ Reading } \\
\hline & & $\mathbf{N}$ & $F$ & $\mathbf{N}$ & $\mathbf{F}$ & $\mathbf{N}$ & $F$ & $\mathbf{N}$ & $\mathbf{F}$ \\
\hline \multirow{4}{*}{ Interpretation } & Categorize & 109 & $39.5 \%$ & 128 & $46.4 \%$ & 111 & $40.2 \%$ & 113 & $40.9 \%$ \\
\hline & $\begin{array}{l}\text { Decode } \\
\text { Significance }\end{array}$ & 121 & $43.8 \%$ & 110 & $39.9 \%$ & 75 & $27.2 \%$ & 132 & $47.8 \%$ \\
\hline & $\begin{array}{l}\text { Clarify } \\
\text { Meaning }\end{array}$ & 128 & $46.4 \%$ & 129 & $46.7 \%$ & 77 & $27.9 \%$ & 177 & $64.1 \%$ \\
\hline & Total & 358 & $43.24 \%$ & 367 & $44.32 \%$ & 263 & $31.76 \%$ & 422 & $50.97 \%$ \\
\hline \multirow{6}{*}{ Analysis } & $\begin{array}{l}\text { Examine } \\
\text { Ideas }\end{array}$ & 72 & $26.1 \%$ & 143 & $51.8 \%$ & 108 & $39.1 \%$ & 96 & $34.8 \%$ \\
\hline & $\begin{array}{l}\text { Identity } \\
\text { Arguments }\end{array}$ & 90 & $32.6 \%$ & 189 & $68.5 \%$ & 111 & $40.2 \%$ & 113 & $40.9 \%$ \\
\hline & $\begin{array}{l}\text { Identity } \\
\text { Reasons and } \\
\text { Claims }\end{array}$ & 100 & $36.2 \%$ & 159 & $57.6 \%$ & 153 & & $55.4 \%$ & $43.1 \%$ \\
\hline & Total & 262 & $31.64 \%$ & 491 & $59.30 \%$ & 372 & $44.93 \%$ & 328 & $39.61 \%$ \\
\hline & $\begin{array}{l}\text { Query } \\
\text { Evidence }\end{array}$ & 81 & $29.3 \%$ & 91 & $33.0 \%$ & 90 & $32.6 \%$ & 93 & $33.7 \%$ \\
\hline & $\begin{array}{l}\text { Conjecture } \\
\text { Alternatives }\end{array}$ & 73 & $26.4 \%$ & 133 & $48.2 \%$ & 93 & $33.7 \%$ & 88 & $31.9 \%$ \\
\hline
\end{tabular}




\begin{tabular}{|c|c|c|c|c|c|c|c|c|c|c|}
\hline Evaluation & $\begin{array}{l}\text { Draw } \\
\text { inductive or } \\
\text { deductive } \\
\text { conclusion }\end{array}$ & 85 & $30.8 \%$ & 166 & $60.1 \%$ & 176 & & $63.8 \%$ & 127 & $46.0 \%$ \\
\hline & Total & 239 & $28.86 \%$ & 390 & $47.10 \%$ & 359 & $43.36 \%$ & 308 & & $37.20 \%$ \\
\hline \multirow{3}{*}{ Inference } & $\begin{array}{l}\text { Assess } \\
\text { credibility of } \\
\text { claims } \\
\end{array}$ & 84 & $30.4 \%$ & 155 & $56.2 \%$ & 112 & $40.6 \%$ & 100 & & $36.2 \%$ \\
\hline & $\begin{array}{l}\text { Assess } \\
\text { quality of } \\
\text { inductive } \\
\text { and } \\
\text { deductive } \\
\text { arguments }\end{array}$ & 69 & $25.0 \%$ & 180 & $65.2 \%$ & 140 & & $50.7 \%$ & 112 & $40.6 \%$ \\
\hline & Total & 153 & $27.72 \%$ & 335 & $60.69 \%$ & 252 & $48.45 \%$ & 212 & & $38.41 \%$ \\
\hline \multirow{4}{*}{ Explanation } & State results & 93 & $33.7 \%$ & 163 & $59.1 \%$ & 156 & & $56.5 \%$ & 93 & $33.7 \%$ \\
\hline & $\begin{array}{l}\text { Justify } \\
\text { procedures }\end{array}$ & 86 & $31.2 \%$ & 145 & $52.5 \%$ & 160 & $58.0 \%$ & 94 & & $34.1 \%$ \\
\hline & $\begin{array}{l}\text { Present } \\
\text { arguments }\end{array}$ & 64 & $23.2 \%$ & 203 & $73.6 \%$ & 171 & & $62.0 \%$ & 74 & $26.8 \%$ \\
\hline & Total & 243 & $29.35 \%$ & 511 & $61.71 \%$ & 487 & & $58.82 \%$ & 261 & $31.52 \%$ \\
\hline \multirow{3}{*}{$\begin{array}{c}\text { Self- } \\
\text { Regulation }\end{array}$} & Selfmonitor & 99 & $35.9 \%$ & 189 & $68.5 \%$ & 171 & & $62.0 \%$ & 109 & $39.5 \%$ \\
\hline & Selfcorrect & 81 & $29.3 \%$ & 221 & $80.1 \%$ & 181 & & $65.6 \%$ & 96 & $34.9 \%$ \\
\hline & Total & 180 & $32.61 \%$ & 410 & $74.28 \%$ & 352 & & $63.77 \%$ & 205 & $37.14 \%$ \\
\hline
\end{tabular}

As it is evident from Table 5, for almost all of the CT core skills, except for the first one, the participants expressed highest frequency of practice during teaching speaking skills. The second language skill during which the CT core skills were most-frequently practiced was reading.

\section{Table 6}

Descriptive statistics of the average scores of the classroom practice of core CT skills

\begin{tabular}{lccccccc}
\hline & $\mathbf{N}$ & Minimum & Maximum & Mean & Std. Deviation & \multicolumn{2}{c}{ Skewness } \\
\hline & Statistic & Statistic & Statistic & Statistic & Statistic & Statistic & Std. Error \\
\hline Listening & 276 & .00 & 1.00 & .3250 & .21280 & .730 & .147 \\
Speaking & 276 & .00 & 1.00 & .5670 & .23933 & -.124 & .147 \\
Writing & 276 & .00 & 1.00 & .4721 & .24801 & .068 & .147 \\
Reading & 276 & .00 & 1.00 & .3931 & .25475 & .521 & .147 \\
Total & 276 & .00 & .97 & .4393 & .20396 & .342 & .147 \\
Valid N (listwise) & 276 & & & & & & \\
\hline
\end{tabular}

Looking into Table 5, it is evident that the highest mean belongs to the speaking skill $(\mathrm{M}=.56)$ while the reading skill $(\mathrm{M}=.391)$ has the lowest mean. Moreover, as almost all of the mean scores were lower than .5 , it is an indicative of relatively low rate of CT skills' practice by EFL teachers.

Note that, as the questionnaire aimed to measure the use of CT skills within each of four language skills (reported in Table 6), to present a more organized description of the results, the average value of the
To answer the third research question, the participants' answers to the Classroom Practice of Core CT Skills questionnaire were averaged under each language skill. Table 6 shows the descriptive statistics of the results. answers to each skill was used. Therefore, the possible range of the scores were 0 to 1 .

In order to see if the mean scores are significant, one sample tests were run. However, as the skewness ratios (Statistics/Std. Error) for listening $(.73 / .147=4.97)$, reading $(.521 / .147=3.54)$ and total score $(.342 / 147=$ 2.20) did not fall within the legitimate range of normal distributions, i.e., \pm 1.96 , they were analyzed using a non-parametric one-sample Wilcoxon Rank Order Test (Table 7), while the skewness ratios for speaking (- 
$.124 / 147=-.84)$ and writing $(.068 / 147=.46)$ fall

parametric one sample t-tests (Table 8 ).

within the range of \pm 1.96 , legitimizing running

Table 7

One-Sample Wilcoxon Rank-Order Test on Average Scores of the Classroom

Practice of Core CT Skills

\begin{tabular}{lccccc}
\hline & $\begin{array}{c}\text { Total } \\
\text { N }\end{array}$ & $\begin{array}{c}\text { Test } \\
\text { Statistic }\end{array}$ & $\begin{array}{c}\text { Standard } \\
\text { Error }\end{array}$ & $\begin{array}{c}\text { Standardized } \\
\text { Test Statistic }\end{array}$ & $\begin{array}{c}\text { Asymptotic } \\
\text { Sig.(2-sided test) }\end{array}$ \\
\hline Listening & 276 & 4024.500 & 1182.791 & -10.504 & .000 \\
Reading & 276 & 8686.000 & 1169.175 & -6.420 & .000 \\
Total & 276 & 12504.000 & 1319.392 & -4.905 & .000 \\
\hline
\end{tabular}

Table 8

One-Sample T-Tests on average scores of the classroom practice of core CT skills

\begin{tabular}{lcccccc}
\hline \multicolumn{7}{c}{ Test Value $=.5$} \\
\hline & & & Sig. (2- & Mean & 95\% Confidence Interval of the Difference \\
\cline { 6 - 7 } & $\mathbf{t}$ & Df & tailed) & Difference & Lower & Upper \\
\hline Speaking & 4.653 & 275 & .000 & .06703 & .0387 & .0954 \\
Writing & -1.866 & 275 & .063 & -.02785 & -.0572 & .0015 \\
\hline
\end{tabular}

The results indicate that in almost all of the language skills, except for speaking, the practice of CT skills is relatively low. Two of the skills, namely listening $(\mathrm{Z}=$ $10.50, \mathrm{p}=.000<.05)$ and reading $(\mathrm{Z}=-6.425, \mathrm{p}=$ $.000<.05)$ obtained significantly low results while the mean of CT skills under the writing skill did not show a significant high/low difference from the expected mean $\left(\mathrm{t}{ }_{(275)}=-1.87, \mathrm{p}=.06>.05\right)$. Moreover, although the speaking skill showed significantly high $\left(\mathrm{t}_{(275)}=\right.$ $4.65, \mathrm{p}=.000<.05)$ practice of CT skills. The overall average of teachers practices was significantly lower $(\mathrm{Z}$
$=-4.91, \mathrm{p}=.000<.05)$ than the expected mean, suggesting that Iranian EFL teachers practice significantly low amount of core CT skills in their classrooms. Figure 3 shows the difference between the observed and expected medians of the practice score.

Note that in analyzing the data, the average values for total amounts were used. As the scale of the practice was measured in a binary fashion (0 or 1$)$, the range of the scores were between 0 and 1 . Therefore, the expected median was 0.5 .

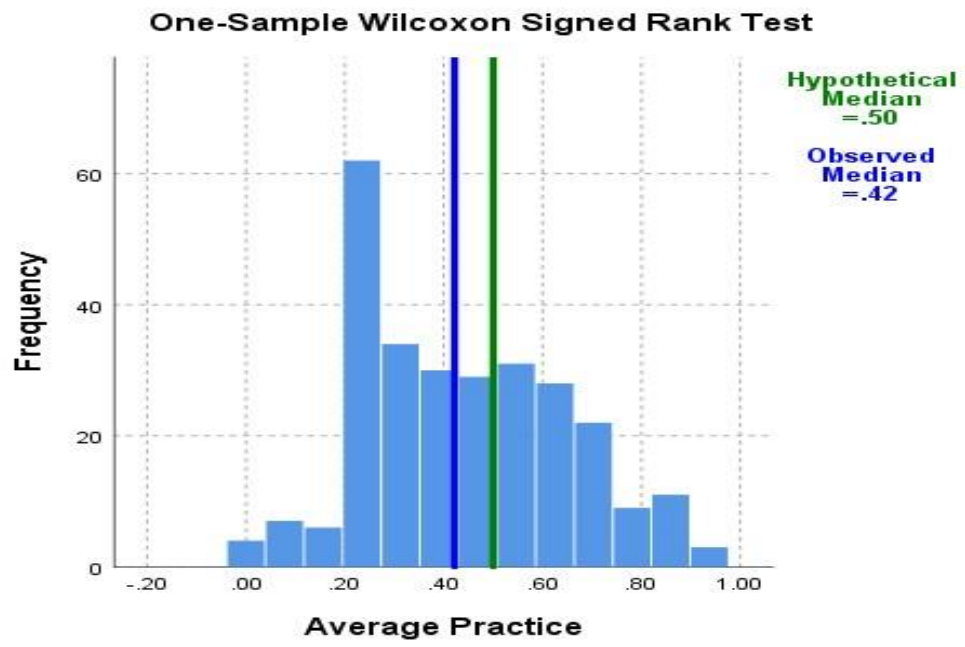

Figure 3. Observed against expected median: practice scores

\section{Discussion and Conclusion}

The main objective of the present descriptive study was to explore EFL teachers' knowledge, practice and attitude towards Critical Thinking Skills. As per the three variables of this study, three questions were posed. It should be reminded here that not much literature in the Iranian EFL context related to this study was found. Thus, discussions on the similarities and differences to this study is limited. So, explanations 
to subsequent results are provided based on assumptions and theories related to CT skills. These results are explained, accordingly.

Firstly, the results of the first question on the knowledge of the EFL teachers showed that (Table 1) all of the mean scores were lower than .5 , indicative of relatively low rate of knowledge of the CT skills. This was found to be significant subsequent to running a One-Sample Wilcoxon Signed Rank Tests on the average scores of the Knowledge of CT Skills (Table 2). To be exact, the total score of the participants was significantly lower than the expected median $(\mathrm{Z}=$ $14.19, \mathrm{p}=.000<.05)$. Therefore, it was concluded that Iranian EFL teachers' knowledge of critical thinking skills is significantly poor.

The results found in the analysis of question one contradicts a study done in Turkey's EFL context [31] which found that EFL teachers have adequate knowledge and understanding about critical thinking (CT). Also, the result of this study is not in line with one study by Asgharheidar and Tahriri [21] that indicated that most Iranian EFL teachers have a rather clear idea of CT. It should be mentioned that their study did not assess teachers' conceptual knowledge of CT skills using a knowledge questionnaire. However, the results lend support to the findings that indicate that Turkish EFL teachers are not in a favorable situation when critical thinking is concerned [32]. Since not much is seen in the review of studies on Iranian EFL teachers' knowledge (knowing the meaning) of the concepts of CT skills, the results can be explained by Purali [33] who mentioned that teachers in Iran are mere consumers of the theories and approaches made by the experts instead of being critical reflective thinkers.

Second, the results of the analysis of the second question on the attitude of the EFL teachers showed that (Table 3) the observed mean score is above the expected mean $(M=3.94>3.5)$. This was found to be significant subsequent to running a One Sample Wilcoxon Signed Rank Tests on the average scores of the attitude on CT Skills (Table 4). To be exact, the total score of the participants was significantly higher than the expected median $(\mathrm{Z}=12.066, \mathrm{p}=.000<.05)$. Therefore, it was concluded that Iranian EFL teachers' attitude towards critical thinking skills is significantly positive.

This result somehow corresponds with that of a study done in Turkey's EFL context [31] which found that EFL teachers have a positive attitude towards critical thinking (CT). Despite their enthusiasm, the study also found that there existed hurdles to their ability to focus on CT. Also, the result of this study is in line with one study done by Asgharheidar and Tahriri [21] that indicated that most Iranian EFL teachers believed in the importance of CT but felt a need for more CT skills training. However, the results contradict a study in Iran that found Iranian EFL teachers who were interviewed expressing an unfavorable attitude towards the integration of critical thinking into their teaching [34]. Their conclusion does echo studies done in EFL contexts in turkey which concluded that teachers have a desire to be trained in CT skills in order to be effective in their classes [32].

Third, the results of the analysis of third question on EFL teachers' practice of CT skills showed that (Table 8) that in almost all of the language skills, except for speaking the practice of CT skills is relatively low among the teachers. Two of the skills, namely listening $(\mathrm{Z}=-10.50, \mathrm{p}=.000<.05)$ and reading $(\mathrm{Z}=-6.425, \mathrm{p}$ $=.000<.05)$ obtained significantly low results while the mean of CT skills under the writing skill did not show a significant high/low difference from the expected mean $(\mathrm{t}(275)=-1.87, \mathrm{p}=.06>.05)$. To provide a clearer picture of these results, details as revealed in the frequency table (4.21) needs to be analyzed.

From the Table 5, it is clear that only $25-35 \%$ of the teachers practiced CT skills in their listening skills training classes. This means that the majority of the teachers did not practice any of the core CT skills significantly in their listening skill training classes. As for the reading classes, only $26-47 \%$ of the teachers reported they practiced CT skills in their reading skill training classes. Interestingly, about $64 \%$ reported they practiced the sub-skill clarifying meaning under the core-skill of Interpretation. This is the only skill that a significant number of teachers practiced in their reading classes.

From the Table 5 again, the analysis of the practice of CT skills in teachers' writing practice classes showed that $56-63 \%$ of the respondents reported that they practiced all the sub-skills under the core CT skills of Explanation and Self -regulation. The number of teachers practicing the other core-skills was not significant with the exception of the sub-skill of identifying reasons and claims under the core skill of Analysis ( $>55 \%$ practiced this skill), the sub-skill of drawing inductive and deductive conclusions under the core-skill of Evaluation ( $>63 \%$ practiced this skill) and the subskill of assessing the quality of inductive and deductive arguments under the core-skill of Inference ( $>50 \%$ practiced this skill).

The only result found in the Frequency Table (5) that contradicts the insignificant practice of CT skills by EFL teachers in their skill-based classes is in the Speaking practice class. A significant number of EFL teachers reported practice of almost all the core CT skills with the exception of Interpretation and Evaluation. Less than $50 \%$ said that they do not practice any of the sub-skills, under the former core skill, while the only sub-skill, under the latter, significantly practiced was the sub-skill of drawing inductive and deductive conclusions $(>60 \%$ practiced this skill). 
Overall, the result to question three shows that EFL teachers do not significantly practice CT skills in almost all of the respective skill-based classes. Therefore, it was concluded that Iranian EFL teachers' practice of critical thinking skills in language skill-based classes is significantly low. Since not much is seen in the literature to either refute or accept this result empirically, explanations to this can be found in suggestions made by researchers in this context. Firstly, the results can be explained by what Mahyuddin et al [12] asserted that there is plenty of room for improvement in incorporating the thinking skills into our curricula. Also, the teachers' insufficient practice of CT skills in classes maybe due to lack of training on creating and incorporating good critical thinking development [14]. This phenomenon can also be explained by related studies that concluded that in the Iranian EFL context teachers are lagging behind in terms of critical skills in education [35] and expressed the need for more training in how to teach these skills [21].

The lack of sufficient practice of CT skills in the listening skills training classes can be explained by the idea that listening is seen as an ability that could be developed without assistance and literature on language learning has revealed a lack of attention towards the skill of listening [36, 37, 38]. Even in the Iranian EFL context, it is not unknown that not much focus is given to practicing listening in classes.

However, the relatively significant number of teachers practicing CT skills in the speaking classes as compared to the other skills is an interesting contribution of this study to existing literature on the practice of CT skill in EFL contexts. This can be explained by the common knowledge that speaking skill is viewed as an important skill in job market. According to Folse [39], being able to speak in a foreign language is important for learners. In Iran, many EFL learners enroll in private language institutes specially to improve speaking skills this has led to the prominence of special conversation classes. Since these classes are comparative crowded, there is a need to make them more learner-centered. This may be one of the reasons why CT skills are most applied in these classes.

The first conclusion of this study is that overall knowledge of Critical Thinking (CT) skills of the sample Iranian EFL teachers was poor. This is significant as it is believed that theory leads to practice. In other words, when a teacher understands the theory behind an effective teaching strategy, method or approach, it could lead to its practice. Thus, the results of this study suggests that lack of knowledge of the meaning of CT construct might contribute to lack of practice of CT skill in class.

The second conclusion was that attitude of EFL teachers toward CT was significantly positive. Finally, this study identified that a significant number of EFL teachers reported practice of almost all the core CT skills. But the majority of the teachers did not practice any of the core CT skills significantly in their listening skill training classes.

\section{Contribution of this Study}

This study provides statistical evidence of the current situation of the EFL teachers' in terms of their knowledge, attitude and practice of CT skills. It also brings to light their lack of knowledge of CT concepts that might suggest the lack of related sub-skills practice in their classes. This study suggests that another important contributing factor of the lack of practice of CT in the EFL context to probably be teachers' lack of understanding of the concept and skills related to the theory of CT.

\section{Implications of the Study}

There is a possibility that the teacher training programs may not sufficiently equip future teachers with the ability of teaching critical skills. For the infusion of critical thinking into the education system, teachers should be educated to model critical thinking [25]. Therefore, it is important to either embed critical thinking into all the courses given in teacher education programs or provide pre-service teachers with practice opportunities in critical thinking through separate courses. So English teachers are expected to get familiar with the concept of CT and decrease it in their learners, as well.

\section{References}

1. Tsui L. Fostering critical thinking in college students: A mixed-methods study of influences inside and outside of the classroom. Los Angeles: University of California. 1998.

2. Giancarlo CA, Facione PA. A look across four years at the disposition toward critical thinking among undergraduate students. J Gen Educ. 2001; 50: 29-55.

3. Moore T. Critical thinking: seven definitions in search of a concept. Stud High Edu. 2013; 38(4): 506522.

4. Rafi MS. Promoting critical pedagogy in language education. Int Res J Art Hum. 2011; 37: 63-73.

5. Liaw M. Content-Based reading and writing for critical thinking skills in an EFL context. Eng Teach Learn. 2007; 31(2): 45-87

6. Kusaka LL, Robertson M. Beyond language: Creating opportunities for authentic communication and critical thinking. Gengo to Bunka. 2006; 14: 21-38.

7. Chamot A. Creating a community of thinkers in the ESL/EFL classroom. TESOL Matter. 1995; 5(5): 1-16. 
8. Tarvin W, Al-Arishi A. Rethinking communicative language teaching: Reflection and the EFL classroom. TESOL Q. 1991; 25(1): 9-20.

9. Chapple L, Curtis A. Content-based instruction in Hong Kong: Student responses to film. Syst. 2000; 28: 419-433.

10. Davidson B. Critical thinking: A perspective and prescriptions for language teachers. Lang Teach. 1994; 18(4): 20-26.

11. Davidson B. Critical thinking education faces the challenge of Japan. Inquiry: Critical Thinking Across the Disciplines. 1995; 14(3): 41-53.

12. Mahyuddin R, Lope Pihie ZA, Elias H, Konting MM. The incorporation of thinking skills in the school curriculum. Kajian Malaysia, Jld, 2004; 22(2): 23-33.

13. Mayfield M. Thinking for yourself: Developing critical thinking skills through reading and writing. (5thed.). London: Harcourt College. 2001.

14. Paul B, Binker AJA, Weil D. Critical thinking handbook: K-3/A guide for remodeling lesson plans in language arts, social studies and science. Sonoma State University, Rohnert Park, CA: Foundation for Critical Thinking. 1990.

15. Fok SC. Teaching critical thinking skills in a Hong Kong secondary school. Asia Pac Educ Rev. 2002; 3(1): 83-91.

16. Mirman J, Tishman S. Infusing thinking through connections. Educ Leader. 1988; 45(7): 64-65.

17. Suhor C. Thinking skills in English and across the curriculum. (ERIC Document Reproduction Service No. ED 250693). 1984.

18. Pica T. Tradition and transition in English language teaching methodology. Syst. 2000; 29: 1-18.

19. Davidson BW, Dunham RA. Assessing EFL student progress in critical thinking with the EnnisWeir Critical Thinking Essay Test. JALT J. 1997; 19(1): 43-57.

20. Tung CA, Chang SY. Developing critical thinking through literature reading. Feng Chia J Hum Soc Sci. 2009; 19: 287-317.

21. Asgharheidari F, Tahriri A. A survey of EFL teachers' attitudes towards critical thinking instruction. J Lang Teach Res. 2015; 6(2): 388-396.

22. Choy SC, Cheah PK. Teacher perceptions of critical thinking among students and its influence on higher education. Int J Teach Learn High Educ. 2009; 20(2): 196204.

23. Stapleton P. Survey of attitudes towards critical thinking among Hong Kong secondary school teachers: Implications for policy change. Think Skill Creativ. 2011; 6: 14-23.

24. Ketabi S, Zabihi R, Ghadiri M. Critical thinking across the ELT curriculum: A mixed methods approach to analyzing L2 teachers' attitudes towards critical thinking instruction. Int J Res Stud Educ. 2013; 2(3): 15-24.
25. Facione PA. Critical thinking: A statement of expert consensus for purposes of educational assessment and instruction. Millbrae, CA: The California Academic Press. 1990; http:/ / files.eric.ed.gov/fulltext/ED315423.pd 26. Shangarffam N, Mamipour M. The impact of teaching critical thinking on intermediate EFL learners' writing skill. Am J Sci Res. 2011; 40: 119-125.

27. Timperley HS. Knowledge and the leadership of learning. Leader Pol Sch. 2011; 10: 1-26.

28. Facione PA. Critical thinking: What it is and why it counts. Insight Assess. 2011; 1: 1-23. http:/ / elementary.nrms.wikispaces.net/file/view/Critic al+Thinking+and +Why

29. Facione PA, Facione NC. The California critical thinking disposition inventory. Millbrae, CA: The California Academic Press. 1992.

30. Riddell T. Critical assumptions: Thinking critically about critical thinking. J Nurs Educ. 2007; 46(3): 121126.

31. Kavanoz S, Akbaş S. EFL teachers' conceptualizations and instructional practices of critical thinking. Int Online J Educ Teach. 2017; 4(4): 418-433. http://iojet.org/index.php/IOJET/article/view/251/1 80

32. Seferoğlu SS, Akbıyık C. Eleştirel düşünme ve öğretimi. Hacettepe Üniversitesi Eŭitim Fakültesi Dergisi, 2006; 30(30): 193-200.

33. Pourali S. Metaphor analysis of beliefs about teaching and learning in the current and ideal situations: A case of professors and students majoring in English language teaching and literature. Unpublished MA thesis, Ferdowsi University of Mashhad. 2011.

34. Mahmoodi-Shahrebabaki M, Yaghoubi-Notash M. Teachers' and learners' attitudes towards critical thinking skills: A case study in the Iranian EFL context. J Appl Linguist Lang Res. 2015; 2(2): 93-106.

35. Ketabi S, Zabihi R, Ghadiri M. Critical thinking across the ELT curriculum: A mixed methods approach to analyzing L2 teachers' attitudes towards critical thinking instruction. Int J Res Stud Educ. 2012; DOI: $10.5861 /$ ijrse.2012.189

36. Chiang C, Dunkel P. The effect of speech modification, prior knowledge, and listening proficiency on EFL lectures learning. J TESOL $Q$. 1992; 26(2): 345-374. http://dx.doi.org/10.2307/3587009

37. Mendelsohn DJ. Teaching listening. J Annu Rev Appl Linguist. 1998; 18: 81-101. http:/ /dx.doi.org/10.1017/S0267190500003494

38. Schmidt-Rinehart BC. The effects of topic familiarity on second language listening comprehension. J Mod Lang. 1994; 78(2): 179-189. http://dx.doi.org/10.1111/j.1540-4781.1994.tb02030.x 39 . Folse KS. The effect of type of written exercise on vocabulary retention. TESOL Q. 2006; 40(2): 273-293. 


\section{KURMANJ}

Copyright: (c) 2021 The Author(s); This is an open-access article distributed under the terms of the Creative Commons Attribution License (http://creativecommons.org/licenses/by/4.0), which permits unrestricted use, distribution, and reproduction in any medium, provided the original work is properly cited.

Citation: Ghaani M, Pauline Roslin V. A Study on the Knowledge, Attitude, and Practice of Critical Thinking Skills among EFL Teachers in Iran. KURMANJ, 2021; 3(2): 14-24.

https://doi.org/10.47176/kurmanj.3.2.14 